\author{
ANDRIY KUDRYACHENKO, \\ State Institution "Institute of World History \\ of the National Academy of Sciences of Ukraine" (Kyiv, Ukraine) \\ e-mail:kudani@ukr.net,.ORCID0000-0002-3833-989X
}

YEVHEN PRYPIK,

State Institution "Institute of World History

of the National Academy of Sciences of Ukraine" (Kyiv, Ukraine)

e-mail: prypik1973@gmail.com,ORCID0000-0003-1334-6003

\title{
VIETNAM'S FOREIGN POLICY AND ITS UKRAINIAN ASPECT IN THE CONTEXT OF THE HISTORICAL AND POLITICAL PROCESSES OF MODERN TIME
}

The article examines the process of forming Vietnam's foreign policy in the context of the historical and political processes of the country in recent history. Paying tribute to the Asian conservatism and seeing a reform of the political system as a threat to the foundations of the statehood and national unity, the Vietnam leaders has chosen its path of social modernization - a "renovation" strategy (in Vietnamese - "Đổi Mói") that has transformed the country within twenty years into another Asian tiger. The "renovation" course was to allow the policy of "open doors" in foreign economic relations. External factors for the successful development of the Vietnam's foreign policy include the ASEAN membership. Due to the many political and socio-cultural factors common to Vietnam and the ASEAN member states (Vietnam joined ASEAN in 1995) and the continued political stability of the country, Vietnam has achieved a particular favor from the investors and trading partners of this association. Considerable attention in the article has also been paid to analyzing the development of political and trade-economic relations between Vietnam and Ukraine in the context of multilateral cooperation. The establishment of diplomatic relations between the two countries and signing the key bilateral agreements has been analyzed. The absence of fundamental differences on key international issues as well as the willingness to develop friendship and mutually beneficial partnership has created the favorable conditions for cooperation between Ukraine and Vietnam within the international organizations. There is much in common in our countries' positions on the proliferation of nuclear weapons and other weapons of mass destruction, counterterrorism, reform of the United Nations etc. Ukraine and Vietnam have traditionally supported each other's nominations for election to the governing bodies of international organizations.

Keywords: modernization; renovation; non-alignment; ASEAN; APEC; ASEM; WTO; UNIDO; joint intergovernmental commission.

\section{Introduction}

In its long history of nearly two thousand years, Vietnam has been under foreign domination for almost a thousand of years. After gaining independence in September 1945, Vietnam was forced again for many decades to assert its right to be free and to constantly protect its land against invaders.

Following the end of World War II, during which Vietnam was under Japanese occupation, the Democratic Republic of Vietnam was proclaimed on September 2, 1945 as a result of the August Revolution. But soon the country became the target of the French aggression, since France sought to restore its colonial rule in Vietnam. The first national liberation war against the French colonialists lasted from 1946 to 1954 and ended with the signing of the Geneva Accords in 1954. According to these accords the French troops left the territory of Vietnam and the country was temporarily divided into two parts along the $17^{\text {th }}$ parallel. The Geneva Accords provided for free elections in both parts of Vietnam in order to determine its future political

ISSN 1728-9343 (Print)

ISSN 2411-3093 (Online) regime and reunification. However, the implementation of the agreements was thwarted by the proclamation of the Republic of Vietnam in the south of the country in October 1955 and the refusal of its president, Ngô Đinh Diêtm, to hold free elections on the territory under his control (Vyznannya Ukrayiny dyplomatychne, 2004).

Meanwhile, the north of the country remained under the control of the Democratic Republic of Vietnam (hereinafter referred to as the North Vietnam), led by the Ho Chi Minh communist regime. As the country's peaceful unification process went to a deadlock, the communist leadership of the North Vietnam decided to support the uprising of the communist forces in the southern Vietnam in order to overthrow the pro-American regime in the Republic of Vietnam and began sending regular units of the North Vietnamese army there (Tran Quang Co, 2005). This led to the United States interfering in this conflict on the side of the government of the Republic of Vietnam and the beginning of a large-scale conflict called as the Vietnam War in the United States or the Resistance War against

SKHID No. 2 (166) March-April 2020 
America in North Vietnam (Seagren \& Henderson, 2018). The war lasted 9 years during 1964-1973 and ended with the signing of the Paris Peace Accords in January 1973. Finally, under the terms of the Paris Peace Accords, the US troops were withdrawn from Vietnam. The Paris Peace Accords envisaged the peaceful unification of two parts of Vietnam after the free and democratic elections in the South of Vietnam, but in March 1975 the North Vietnamese forces invaded the territory of the Republic of Vietnam and quickly captured it. On July 2, 1976 the unified independent Vietnamese state, the Socialist Republic of Vietnam, was proclaimed (Bilorus, 2009: 16).

\section{Methods}

The methodology of the research is based on the application of general historical methods of scientific research, namely: historical-comparative, typologization (historicaltypological) and systematic analysis. Using the historicalcomparative method, the process of formation of the Vietnam's foreign policy is explored. In particular, the analysis of the Vietnam's political system and its effectiveness for the foundations of the statehood and national unity is conducted. This allows a comprehensive overview and comparison of all aspects of the foreign policy formation that was one of the conditions for the social modernization of the country.

The historical-typological method makes it possible to identify the reasons and methods of the renovation strategy that has transformed Vietnam within twenty years into another Asian tiger. In addition, the historical-typological method helps to reconstruct the renovation course of the country that allowed Vietnam to introduce the policy of "open doors" in foreign economic relations and to determine the level of its effectiveness. Using the systematic analysis method, many political and socio-cultural factors that resulted in the successful development of the Vietnam's foreign policy can be explored and its importance for the continued political stability of the country can be determined.

\section{Results and Discussion}

After the victory of the Vietnamese communists and the reunification of two parts of Vietnam, the policy of the Communist China towards its southern neighbor began to change. The Chinese leadership was obviously against the emergence of a strong pro-Soviet state near its borders (in November 1978 Vietnam concluded a long-term friendship and cooperation agreement with the Soviet Union) and put pressure on its southern neighbor. Consequently, China seized the disputed Paracel Islands in 1974, which, according to the Vietnamese side, had been part of Vietnam for several centuries (Turcsanyi, 2014).

Another striking example of the clashes between the Chinese and Soviet "spheres of influence" in this region was the events in Cambodia, where in 1975 the Khmer Rouge, headed by Pol Pot, came to power and chose the communist China as their sole foreign policy ally. A series of border conflicts between Vietnam and Cambodia (then called Democratic Kampuchea) in early 1979 led to a fullscale invasion of Vietnam into the country and the overthrow of the pro-Chinese Khmer Rouge regime (Carlile, 2019). This subsequently led to the establishment of pro-Vietnam (and therefore of the pro-Soviet) regime in Cambodia which pushed China to "teach its southern neighbor a lesson". In February-March 1979 a large-scale border conflict broke out between China and Vietnam, which claimed the lives of some 40,000 people and ended with the withdrawal of
Chinese troops from the Vietnamese territory and the restoration of the border between China and Vietnam.

Vietnamese occupation of Cambodia lasted from 1979 to 1989 and ended with the withdrawal of Vietnamese troops from this country. During the same period of time the permanent minor conflicts and provocations continued on the border between Vietnam and China. The relationship between China and Vietnam was fully restored and normalized only in 1991, following the summit of highlevel negotiations between the leadership of two countries (Ly Bang, 1990).

At the same time, under the influence of "perestroika" in the Soviet Union and reforms in China, the Vietnamese leadership in 1986 announced the launch of the "renovation policy" ("Đổi Mới").

The new course of the Vietnamese leadership provided for the gradual and cautious liberalization of socioeconomic life under the strict control of the state and the Communist Party of Vietnam while preserving the formal attributes of the socialist system in the country (Elliott, 2014). In 1992 the new constitution of the Socialist Republic of Vietnam was adopted outlining the foreign policy principles of the country in Article 14 of this document. These principles determine that the Socialist Republic of Vietnam seeks to develop relations and cooperation with all countries of the world without depending on their political and social order, on the principles of respect for the independence, sovereignty and territorial integrity, noninterference in internal affairs, equality and taking into account mutual interests. Vietnam seeks to strengthen solidarity, friendship and cooperation with the socialist states and neighboring countries; actively supports and participates in the common struggle of all peoples of the world for peace, national independence, democracy and social progress (Schuler, 2020).

Currently Vietnam's foreign policy is characterized by the following main trends:

- development of the bilateral relations with all countries of the world, giving priority to the ASEAN countries;

- strengthening relations with traditionally friendly countries;

- active development of relations with the Asian, African and Latin American countries;

- deepening relations with industrially developed countries of Europe and North America, particularly in the financial, investment, scientific and technological spheres;

- multilateral diplomacy;

- "economic diplomacy" and active participation in regional and international economic integration

The main objective of Vietnam's foreign policy is to ensure favorable external conditions for transforming Vietnam by 2020 into an industrially developed and politically influential regional state. The principles of nonalignment and friendly equidistance remain dominant for Vietnam's foreign policy (Kudryachenko, Rudych, Khramov, 2004).

In the regional context, Vietnam pays special attention to cooperation with ASEAN (Association of Southeast Asian Nations) countries, both in terms of interstate relations and at the level of ASEAN's structures and forums. Vietnam considers its membership in ASEAN as a means of economic and political involvement into the regional integration processes (Hieu Huu, 2020). Participation in the Association of Vietnam uses, among other things, as a tool for distance from all world powers, capable of influencing the foreign or domestic policies of the country. 
Vietnam uses the participation in ASEAN as a tool to distance itself from all the world powers that are capable of influencing the foreign or domestic policies of the country. One of the characteristic features of ASEAN is the unanimity of non-interference in each other's internal affairs. Vietnam has consistently upheld this principle. At the same time the diversification of forms of the regional cooperation (ASEAN + 6, ASEAN + 3, ASEAN + 1, East Asian Summit etc.) contributes to balancing the national interests and overcoming conflicts (Nguyen Hoang, Luong Vinh Quoc \& Bui Hoang, 2019). The leaders of ASEAN countries consider the economic cooperation as an important component of the transition to political interaction and the promotion of the cultural and humanitarian sphere of the Southeast Asian countries (Angie Ngoc \& Crinis, 2018).

Official Hanoi is paying close attention for the further development of relations with its neighbors, Laos and Cambodia, and trying to play the role of the leader of CLMV group (Cambodia, Laos, Myanmar, Vietnam) within ASEAN. Vietnam is actively engaging with its neighbors through the so-called "Development Triangle" and the Greater Mekong countries. Vietnam has also repeatedly acted as a sort of mediator for Myanmar in contacts with the critics of this country's previous regime.

Vietnam has historically paid an increased attention to its cooperation with the People's Republic of China. Official Beijing, using both political and economic leverage, persistently demonstrates its desire to set an example for the Socialist Republic of Vietnam (Reeves, 2018). In doing so, official Beijing combines political activities, notably the constant exchange of official visits, with the active encouragement of its supporters in Hanoi. The $70^{\text {th }}$ anniversary of the establishment of diplomatic relations between the two countries will be celebrated in 2020 with the Year of China in Vietnam and the Year of Vietnam in China to be held respectively. At the same time the process of the demarcation of land borders between the two countries has been completed.

In recent years China has remained Vietnam's largest trading partner. In 2019 the annual turnover of the two countries amounted to US\$ 117 billion. At the same time the relations between two countries, given the existing territorial disputes over the Paracel Islands and the Spratly archipelago, are quite complicated. In 2012-2014 Vietnam and China continued to dispute the ownership of islands after a series of incidents in the area, including the Chinese warships repulse to the navigation of the Vietnamese fishing vessels (Lai, 2019).

Political and economic ties with Japan, which is one of the leaders in terms of the foreign direct investment into the Vietnamese economy, are consistently high on the agenda. In 2012-2017 a number of Vietnamese highranking officials, including the President of the Socialist Republic of Vietnam, the Prime Minister and the Secretary General of the Communist Party of Vietnam, visited Japan. In particular, during the visit of the Head of the Vietnamese Government to Japan a loan agreement totaling US\$ 1,2 billion was concluded between the Japanese Agency for International Cooperation and the Ministry of Finance of Vietnam. In addition Japan has pledged two grants totaling US\$ 900 million to Vietnam in order to develop the country's space program. At the same time in 2012 the Government of Japan allocated US\$1,9 billion to Vietnam under the Official Development Assistance program.

One can draw attention to the fact that, when the Japanese Prime Minister S.Abe paid a visit to Vietnam in January 2013 , it was his first foreign visit as the newly elected Head of the Government of Japan. Thereby, the year of 2013 was also declared a year of VietnameseJapanese friendship.

Later, in March 2014 the state visit of the President of Vietnam T.T. Sang to Japan took place at the invitation of the Japanese Emperor Akihito. The main objective of this visit was to deepen the strategic partnership between the two countries and to further intensify cooperation in different fields. Of particular note is the fact that the above mentioned state visit of T.T. Sang to Japan was the second visit of the President of Vietnam since the establishment of diplomatic relations between the two countries in 1973 .

Currently, the relations between Vietnam and the United States are getting closer. Vietnam is considering the cooperation with US through the prism of economic benefits (United States is the largest market for the Vietnamese goods) as well as the counterbalance to the expansion of China in the region. For example, the statement by the former US Secretary of Defense R. Gates during his visit to Hanoi was indicative for the prospect of US presence in the region. In particular, he stated that "... for a long time, the United States has been an active player in the region and will continue to be involved not only in the economic issues but also in the regional security issues" (Kudryachenko, Rudych, Khramov, 2004: 217). This reaffirmed the US position on the necessity for multilateral disputes, and not exclusively in a bilateral format between the countries intersecting in the South China Sea as suggested by China.

In the summer of 2012 the joint US-Vietnam naval exercises took place which was extremely negatively perceived by China. During the $3^{\text {rd }}$ round of the VietnamUS Dialogue on Defense Policy the Socialist Republic of Vietnam and the United States agreed to continue the practice of joint exercises at sea. In response, the Deputy Foreign Minister of the People's Republic of China said that some of China's neighbors were "playing with fire" and warned the United States against interfering in these affaires (Albuyeh \& Paradis, 2018).

In 2013 the President of Vietnam T.T. Sang held an official visit to the United States which became the secondever visit by the Head of the Socialist Republic of Vietnam to the United States after the normalization of diplomatic relations between the two countries in 1995. Bilateral relations between the two countries continue to develop intensively, especially after the establishment of a comprehensive partnership between Vietnam and the United States in 2013. The US leadership emphasizes the important role of Vietnam in the region of the Southeast Asia and expresses the desire to strengthen its cooperation with this country. In 2016, during his visit to Vietnam, the US President B. Obama announced the complete lifting of the US arms embargo on Vietnam. This decision is intended to help Vietnam enhance the defense capabilities of the Vietnamese naval forces and the security of its sea borders. In light of the above, it should be noted that US policy towards Vietnam is fully in line with the US strategy for shifting the balance of power in the Southeast Asia region.

At the same time the trade cooperation between Vietnam and the United States is developing at a rapid pace. In 2018 the trade between two countries reached a level of US\$ 60.3 billion, 133 times higher than in 1995 (the year of the normalization of diplomatic relations between Vietnam and the United States). In addition Vietnam had a positive trade balance with United States of nearly US\$ 35 billion in 2018. 
It should also be noted that the US market ranks first in terms of Vietnamese exports amounting to US\$ 47.5 billion in 2018, ahead of China, Japan and all EU countries combined.

However, despite ongoing rapprochement, a number of differences on some pressing issues still remain on the agenda such as protection of human rights and religious freedom in Vietnam, overcoming the effects of the US Air Force use of Agent Orange during the Vietnam War etc. In addition, during all the meetings the Vietnamese government calls on the United States to recognize the Socialist Republic of Vietnam as a country with market economy and to include Vietnam into the Generalized System of Preferences.

One of Hanoi's foreign policy priorities remains Europe. For the European Union cooperation with Vietnam is of great interest because its economic and political positions in Southeast Asia are significantly downscale to those of the United States and China. Vietnam is also interested in developing relations with the European Union as this vector forms a significant counterbalance to relations with its main trading partners - the United States, China, and Japan. In June 2019 the Socialist Republic of Vietnam and the European Union signed a free trade agreement (FTA). Earlier the Partnership and Comprehensive Cooperation Agreement between Vietnam and the EU was also concluded. The EU market ranks second in terms of Vietnamese exports (US\$ 42.5 billion in 2018), and the European Union is the second largest investor in the economy of Vietnam. Vietnam has established strategic partnership relations with Germany, France, the United Kingdom, Spain and the Netherlands. However, migration policy and human rights remain the main issues on which the parties cannot find consensus so far.

The relations of strategic partnership with the Russian Federation are quite close and dynamic. Visits are regularly exchanged at the high and highest levels. The official visits of the President of the Russian Federation to Vietnam took place in 2001, 2006, 2010 and 2013. And the last visit of the President V.Putin to Vietnam occurred in 2017 when he participated in the APEC summit held in Danang. At the invitation of the Russian leadership the Secretary General of the Central Committee of the Communist Party of Vietnam officially visited the Russian Federation in 2002, 2010 and 2014, and the President of Vietnam officially visited Russia in 2004, 2008, 2012 and 2017. Also the leaders of two countries regularly meet in the framework of the multilateral international forums such as APEC, ASEM, ASEAN + Russia etc. In November 2013, following a state visit by the President of the Russian Federation to Vietnam, a joint statement was adopted to further strengthen the relationship of a comprehensive strategic partnership between the two countries. In order to further develop this relationship the year of 2019 was proclaimed the cross Year of Vietnam in Russia and Russia in Vietnam.

An important element of the economic cooperation between the Russian Federation and Vietnam is the cooperation in the energy sector, in particular, the oil and gas sector where the main object is the Russian-Vietnamese (former Soviet-Vietnamese) joint venture for oil and gas production on the continental shelf of the South of Vietnam - "Vietsovpetro" (65\% of the country's oil production). The joint energy projects are underway, including the expansion and modernization of Vietnam's "Dung Quất" refinery and the construction of the first nuclear power plant in Vietnam. In October 2010, as part of President Medvedev's visit to Vietnam, an intergovernmental agreement was signed which provided for the construction of the "Ninh Thuan-1" nuclear power plant, the first nuclear power plant in Vietnam. The agreement on US\$ 8 billion loan by the Russian Federation to Vietnam for the construction of the "Ninh Thuan-1" nuclear power plant as well as an additional US\$ 500 million loan for the establishment of the nuclear science and technology center in Vietnam was concluded in November 2011 during the visit of the President of Vietnam to Russia. The Russian Federation has confirmed its readiness to begin training personnel for the future nuclear power plant in Vietnam and to educate the Vietnamese nuclear engineers in the Russian universities and institutes. The construction of the "Ninh Thuan-1" nuclear power plant was scheduled to begin in 2014 with the first reactor planned to be commissioned in 2020 and the last fourth reactor - in 2024. Later, in November 2015 the date of commissioning the nuclear power plant was postponed from 2024 to 2028, and in November 2016 Vietnam suspended the construction of the nuclear power plant. The reason for this suspension was a decline in energy consumption in Vietnam as well as decline of the world oil and coal prices. Vietnam has announced that in the country's energy plan until 2030 the nuclear power has not been budgeted for.

The military sector is also one of the main areas of cooperation between the Russian Federation and Vietnam. For example, a number of contracts for the supply of weapons and military equipment to Vietnam totaling US\$ 1.6 billion were signed during the visit of the Prime Minister of Vietnam to Russia in 2009 including the supply of Russian submarines and fighters.

The Russian companies benefit greatly from the highlevel regular political contacts between the two countries and the systematic work of the joint intergovernmental bodies (Lokshin, 2019). The total trade turnover between Vietnam and Russia reached US\$ 6.1 billion in 2018. However, the situation with the Vietnamese nationals in Russia due to the increasing discrimination towards them and the restrictions on their entrepreneurial activity as well as the restrictive sanctions by Russia on the import of the Vietnamese products are rather acute issues of bilateral relations.

In recent years the rapprochement between Vietnam and India continued. During the visit of Indian President to Vietnam in 2014 two countries agreed to continue the cooperation at regional and international forums and reaffirmed their commitment to support each other's candidacy for non-permanent membership of the UN Security Council. The leaders of Vietnam and India agreed on the importance of ensuring the safety of navigation in the South China Sea, settling disputes in this region peacefully and on the basis of respect for the international law, in particular, the 1982 United Nations Convention on the Law of the Sea and compliance with the Declaration of Conduct in the South China Sea.

Vietnam relations with the countries of Africa, Middle East, South Asia, Latin America and the non-aligned countries are also constantly developing.

Vietnam's activity in the framework of international structures such as APEC, ASEM, International Organization of La Francophonie, Non-Aligned Movement is fruitful in terms of integrating Vietnam into the world community. The most recent foreign policy milestones for Vietnam were: election as non-permanent member of the UN Security Council (in 2007 and in 2019), membership in the World Trade Organization (in January 2007), ratification of the ASEAN Charter (in March 2008), chairmanship in 
ASEAN (in 2010 and in 2020). In June 2019 Vietnam for the second time was formally elected a non-permanent member of the UN Security Council for the period 20202021. This is a testament to the fact that Vietnam is trying to play a more prominent role in the United Nations which praise Vietnam's progress in poverty reduction and the achievement of the Millennium Goals.

The establishment of the diplomatic relations between Ukraine and the Socialist Republic of Vietnam on January 23, 1992 accelerated collaboration in all spheres of the bilateral cooperation. Since then, the efforts of the two countries have created a sufficiently developed legal framework for cooperation at the intergovernmental and interinstitutional levels (Madisson, Shakhov, 2003: 56-59).

Among the bilateral agreements concluded are the Agreement between the Government of Ukraine and the Government of the Socialist Republic of Vietnam on trade and economic relations (1992), the Agreement on the establishment of the Intergovernmental Ukrainian-Vietnamese Commission on trade, economic and scientific and technical cooperation (1993), the Intergovernmental Agreement on the promotion and protection of investments (1994) as well as the Agreement between the Government of Ukraine and the Government of the Socialist Republic of Vietnam on Cooperation in the military and technical sector (1994).

In 1993 the Embassy of the Socialist Republic of Vietnam opened in Ukraine and in 1997 the Embassy of Ukraine in Vietnam started its operation. During 1993-1994 the exchange of the official visits at the level of Ministers of Foreign Affairs of Ukraine and Vietnam took place and a number of important bilateral agreements were signed (Kudryachenko, 2010: 3-4).

During the visit of the Prime Minister of Vietnam V.V.Kiêt to Ukraine in June 1994 the decision for the establishment of the Intergovernmental Ukrainian-Vietnamese Commission on trade, economic, scientific and technical cooperation was made and the first meeting of the Commission took place in Hanoi in April 1995.

The highest level of relations was initiated by the state visit of the President of Ukraine L. Kuchma to Vietnam in 1996. During the visit the interstate Agreement on the principles of relations between the two countries was signed. In the year of 2000 the President of Vietnam T.Đ.Lương paid a state visit to Ukraine. The visit ended with a series of intergovernmental and interagency documents signed by two sides. In January 2003 the Chairman of the National Assembly of Vietnam N.V.An paid an official visit to Ukraine.

The development of bilateral Ukrainian-Vietnamese relations was facilitated by the official visit of the Chairman of the Verkhovna Rada of Ukraine V. Lytvyn to Vietnam which took place in December 2010. In March 2011 the President of Ukraine had the state visit to Vietnam. During this visit, a number of bilateral documents were signed. The main outcome of the visit was the Joint Statement on establishing the relations of comprehensive cooperation and partnership between Ukraine and Vietnam signed by the Presidents of two countries. In the Joint Statement the main directions, forms and mechanisms of further cooperation on a wide range of bilateral and international issues are outlined. The document also designates the priorities for the cooperation between Ukraine and Vietnam (Hryshchenko, 2011).

In October 2011 the Prime Minister of Vietnam N.T. Dũng officially visited Ukraine and in November 2012 the Prime Minister of Ukraine paid an official visit to Vietnam. In April
2015 the Ukrainian parliamentary delegation participated in the $132^{\text {nd }}$ Assembly of the Inter-Parliamentary Union. In September 2017 the Minister of Foreign Affairs of Ukraine P. Klimkin paid an official visit to Vietnam and held talks with his Vietnamese counterpart P.B.Minh and with the Prime Minister of Vietnam N.X. Phúc. During his talks in Vietnam, the Foreign Minister of Ukraine discussed the prospects of developing relations between the two countries in the political, trade, economic and humanitarian spheres.

As of the end of 2019 the Ukrainian-Vietnamese legal framework has more than fifty bilateral documents of various levels. The significant legal agreement framework of the bilateral relations is generally a positive phenomenon, but it does not cover all possible areas of cooperation. However, a number of cross-sectoral agreements, protocols on cooperation between administrative units, education and science institutions of Ukraine and Vietnam contribute to the development of bilateral relations.

In particular, Ukraine supported Vietnam's candidacy for the non-permanent membership of the UN Security Council for the period of 2008-2009. In addition, the two countries agreed to support each other's candidacy in the election of the non-permanent members of the UN Security Council for the period of 2016-17 (Ukraine's candidacy) and the period of 2020-21 (Vietnam's candidacy). Vietnam actively promoted Ukraine on its path to WTO accession and supported Ukraine's candidacy for the role of observer in the International Organization of La Francophonie. Ukraine supported Vietnam's candidacy in the election to ECOSOC for the period of 2016-2018 in exchange for Vietnam's support of Ukraine's candidacy to ECOSOC for the period of 2019-2021. Vietnam agreed to support Ukraine's candidacy of the External Auditor for UNIDO for the period of 2014-2016 in exchange for Ukraine's support of Vietnam's candidacy for the membership of the UNESCO World Heritage Committee for the period of 2013-2017 (Pam Doan Nam, URL...).

At the same time, the Vietnam supported Ukraine's candidacy as the presiding country in the Agricultural Market Information System (AMIS) for the period of 2014-2016 as well as Ukraine's candidacy for the election to the Council of Administration of the Universal Postal Union for the period of 2012-2016.

The trade and economic relations between Ukraine and Vietnam are regulated by the following high-level bilateral bodies:

- the Ukrainian-Vietnamese Intergovernmental Commission for Trade, Economic, Scientific and Technical Cooperation which was established in 1994 and includes representatives of the Ministry of Economic Development, Trade and Agriculture of Ukraine, Ministry of Foreign Affairs, Ministry of Infrastructure of Ukraine, Ministry of Energy and Coal Mining, Ministry of Education and Science of Ukraine, National Academy of Sciences of Ukraine, Ministry of Healthcare of Ukraine etc. The last $14^{\text {th }}$ joint meeting of the Intergovernmental Commission was held on October 910, 2017 in Kyiv, Ukraine;

- the Ukrainian-Vietnamese Joint Subcommission on the Scientific and Technical Cooperation (the last $5^{\text {th }}$ meeting of the Subcommission was held on December 8-9, 2011 in Hanoi, Vietnam);

- the Ukrainian-Vietnamese Intergovernmental Coordination Commission on the Military and Technical Cooperation (the last $16^{\text {th }}$ meeting of the Commission was held on March 27-31, 2017 in Kyiv, Ukraine). 


\section{Conclusions}

The foreign policy of Vietnam is aimed at providing favorable external conditions for the introduction of the renovation strategy, the implementation of the economic development plans and socio-economic reforms, the formation of the system of international relations favorable for the peaceful and sustainable development of the country. Hence - there is desire to strengthen the international security, to overcome the negative tendencies in regional relations, to resolve the conflict situations, to develop a "code of conduct" for the countries of the AsiaPacific region. The relatively "weak" Vietnam, in pursuit of these goals, constantly emphasizes the so-called "friendly to all" policy, receiving considerable dividends from it.

The lack of fundamental differences on topical international issues as well as the willingness to develop friendship and mutually beneficial partnership has created favorable conditions for cooperation between Ukraine and Vietnam within the international organizations. The regular working contacts between the two countries' missions to the United Nations are maintained. There is much in common in both countries' positions on the proliferation of nuclear weapons and other weapons of mass destruction, counter-terrorism, reform of the United Nations etc. Ukraine and Vietnam have traditionally supported each other's nominations in the election to the governing bodies of international organizations.

Therefore, maintaining stability and balance of the political dialogue between the two countries, the regularity in holding meetings of the joint bodies and the strict adherence to the agreements reached are the preconditions for the successful realization of Ukraine's national economic interests in relations with Vietnam. The constructive cooperation with Vietnam makes it possible for Ukraine to further enter into promising trade, economic and investment markets not only of ASEAN countries but also of more powerful countries that are members of APEC.

\section{REFERENCES}

Albuyeh, R., \& Paradis, M. (2018). Thawing Rivalries and Fading Friendships: An Experimental Approach to Rapprochement and Alienation. Political Psychology, 39(4), 811-827. DOI: https://doi.org/10.1111/pops.12441

Angie Ngoc, T., \& Crinis, V. (2018). Migrant Labor and State Power: Vietnamese Workers in Malaysia and Vietnam. Journal of Vietnamese Studies, 13(2), 27-73. DOI: https://doi.org/10.1525/ vs.2018.13.2.27

Bilorus, O. H. (2009). Ukrayina v systemi hlobalnykh transformatsiy. Hlobalizatsiya i hlobalne upravlinnya: istorychnyy, sotsialnyy ta politolohichnyy vymiry. Kyiv (In Ukrainian).

Carlile, A. (2019). Thayer Background Brief. Vietnam's Intervention in Cambodia: Invasion or Liberation? Thayer Consultancy Background Brief. Retrieved from https://ru.scribd.com/ document/396717036/Thayer-Background-Brief-Vietnam-sIntervention-in-Cambodia-Revisited-1979-2019

Elliott, David W.P. (2014). Changing worlds: Vietnam's Transition from Cold War to Globalization. Oxford University Press.

Hieu Huu, N. (2020). Impact of Foreign Direct Investment and International Trade on Economic Growth: Empirical Study in Vietnam. Journal of Asian Finance Economics and Business, 7(3), 323-331. DOI: https://doi.org/10.13106/jafeb.2020.vol7.no3.323

Hryshchenko, K.I. (2011). Ukrayina hraye svoyu hru. Den, Mars, 22 (In Ukrainian).

Kudryachenko, A. I. (2010). Yevropeyskyy vybir Ukrayiny: dosyahnennya, problemy i perspektyvy. Viche. 18: 3-4. (In Ukrainian).
Kudryachenko, A. I., Rudych, F. M., Khramov, V. O. (2004). Heopolityka. Kyiv. (In Ukrainian).

Lai, C. (2019). A Coercive Brotherhood: Sino-Vietnamese Relations from the 1990s to 2018. Journal of Contemporary China. DOI: https://doi.org/10.1080/10670564.2019.1645484

Lokshin, G. M. (2019). Nguyen Co Thach - architect of modern diplomacy of Vietnam; Nguen Ko Tkhat' - tvorets sovremennoi diplomatii V'etnama. Aziya i Afrika segodnya (8). DOI: https:// doi.org/10.31857/s032150750005789-9

Ly, Bang (1990). "Diplomatic Diary" and "Cooperation for Peace". Retrieved from http://vietnam.org/chengdu-1990/ly-bang-tietlo-hoi-nghi-thanh-do-1990.html.

Madisson, V. V., Shakhov, V. A. (2003). Suchasna ukrayinska heopolityka. Kyiv: Lybid, S. 56-59. (In Ukrainian)

Nguyen Co Thach (2013). Architect of the Modern Vietnam's Diplomacy. Pam Doan Nam. Retrieved from https://baoquocte.vn/ (In Viet.)

Nguyen Hoang, L., Luong Vinh Quoc, D., \& Bui Hoang, N. (2019). Effects of Foreign Direct Investment and Human Capital on Labour Productivity: Evidence from Vietnam. Journal of Asian Finance Economics and Business. 6(3), 123-130. DOI: https:/ /doi.org/10.13106/jafeb.2019.vol6.no3.123

Reeves, J. (2018). Imperialism and the Middle Kingdom: the Xi Jinping administration's peripheral diplomacy with developing states. Third World Quarterly, 39(5), 976-998. DOI: https:// doi.org/10.1080/01436597.2018.1447376

Schuler, P. (2020). VIETNAM'S FOREIGN POLICYUNDER DOI MOI. Pacific Affairs. 93(1), 220-222.

Seagren, C. W., \& Henderson, D. R. (2018). Why We Fight A Study of U.S. Government War-Making Propaganda. Independent Review. 23(1). 69-90.

Tran Quang Co. (2005). Memories. State political edition's house. Hanoi.

Turcsanyi, R. Q. (2014). The distribution of power in east asia in the post-crimea world: the un-checked china's rise?

Vyznannya Ukrayiny dyplomatychne (2004). Ukrayinska dyplomatychna entsyklopediya. Vol.1. Kyiv, 194-200 (In Ukrainian).

\section{LIST OF REFERENCE LINKS}

Білорус О. Г. Україна в системі глобальних трансформацій. Глобалізація і глобальне управління: історичний, соціальний та політологічний виміри. Київ, 2009.

Визнання України дипломатичне / Українська дипломатична енциклопедія. Київ, 2004. Т.1. С. 194-200.

Грищенко К. І. Україна грає свою гру. День. 22 березня 2011 р.

Кудряченко А. І. Європейський вибір України: досягнення, проблеми і перспективи. Віче. 2010. № 18. С. 3-4.

Кудряченко А. І., Рудич Ф. М., Храмов В. О. Геополітика. К., 2004.

Мадіссон В. В., Шахов В. А. Сучасна українська геополітика. Київ: Либідь, 2003. С. 56-59.

Albuyeh R. \& Paradis M. Thawing Rivalries and Fading Friendships: An Experimental Approach to Rapprochement and Alienation. Political Psychology. 2018. 39(4), 811-827. DOI: https://doi.org/ 10.1111/pops.12441

Angie Ngoc T. \& Crinis V. Migrant Labor and State Power: Vietnamese Workers in Malaysia and Vietnam. Journal of Vietnamese Studies. 2018. 13(2). 27-73. DOI: https://doi.org/10.1525/vs.2018.13.2.27

Carlile A. Thayer Background Brief. Vietnam's Intervention in Cambodia: Invasion or Liberation? January 9, 2019. URL: https:/ /ru.scribd.com/document/396717036/Thayer-BackgroundBrief-Vietnam-s-Intervention-in-Cambodia-Revisited-19792019

Elliott David W. P. Changing worlds: Vietnam's Transition from Cold War to Globalization. Oxford University Press; Reprint edition (March 3, 2014). 
Hieu Huu N. Impact of Foreign Direct Investment and International Trade on Economic Growth: Empirical Study in Vietnam. Journal of Asian Finance, Economics and Business. 2020. 7(3), 323331. DOI: https://doi.org/10.13106/jafeb.2020.vol7.no3.323

Lai C. A Coercive Brotherhood: Sino-Vietnamese Relations from the 1990s to 2018. Journal of Contemporary China. 2019. DOI: https://doi.org/10.1080/10670564.2019.1645484

Lokshin G. M. Nguyen Co Thach - architect of modern diplomacy of Vietnam; Nguen Ko Tkhat' - tvorets sovremennoi diplomatii V'etnama. Aziya i Afrika segodnya (8). 2019. DOI: https:// doi.org/10.31857/s032150750005789-9

Ly Bang. "Diplomatic Diary" and "Cooperation for Peace". URL: http://vietnam.org/chengdu-1990/ly-bang-tiet-lo-hoi-nghithanh-do-1990.html

Nguyen Co Thach - Architect of the Modern Vietnam's Diplomacy. Pam Doan Nam. URL: https://baoquocte.vn/

Nguyen Hoang L., Luong Vinh Quoc D., Bui Hoang N. Effects of Foreign Direct Investment and Human Capital on Labor Pro- ductivity: Evidence from Vietnam. Journal of Asian Finance Economics and Business. 2019. 6(3). 123-130. DOI: https:// doi.org/10.13106/jafeb.2019.vol6.no3.123

Reeves J. Imperialism and the Middle Kingdom: the Xi Jinping administration's peripheral diplomacy with developing states. Third World Quarterly. 2018. 39(5). 976-998. DOI: https:// doi.org/10.1080/01436597.2018.1447376

Schuler P. VIETNAM'S FOREIGN POLICY UNDER DOI MOI. Pacific Affairs. 2020. 93(1). 220-222.

Seagren C. W., Henderson D. R. Why We Fight A Study of U.S. Government War-Making Propaganda. Independent Review. 2018. 23(1). 69-90.

Tran Quang Co. Memories. State political edition's house. Hanoi, 2005.

Turcsanyi R. Q. THE DISTRIBUTION OF POWER INEASTASIA IN THE POST-CRIMEAWORLD:THEUN-CHECKED CHINA'S RISE? 2014.

Андрій Кудряченко,

ДУ "Інститут всесвітньої історії НАН України" (м. Київ, Україна)

e-mail: kudani@ukr.net, ORCID0000-0002-3833-989X

Свген Припік,

ДУ "Інститут всесвітньої історії НАН України" (м. Київ, Україна)

e-mail: prypik1973@gmail.com,ORCID0000-0003-1334-6003

\section{ЗОВНІШНЯ ПОЛІТИКА В'ЄТНАМУ ТА ІЇ̈ УКРАЇНСЬКИЙ АСПЕКТ У КОНТЕКСТІ ІСТОРИЧНИХ ТА ПОЛІТИЧНИХ ПРОЦЕСІВ СУЧАСНОСТІ}

У статті розглядається процес формування зовнішньої політики В'єтнаму з огляду на історичні та політичні процеси, що відбувались у країні протягом другої половини XX сторіччя та перших десятиліть нинішнього. Аналізуються реформи політичної системи В'єтнаму, які, через стратегію оновлення, призвели до суспільної модернізації країни та перетворили її на потужну економічну державу. Проаналізовано головні чинники успіху зовнішньої політики В'єтнаму, до яких треба віднести вступ країни до такої організації як АСЕАН, що відбувся у 1995 році. У статті доведено, що завдяки багатьом політичним і соціокультурним чинникам, що є спільними для В'єтнаму і держав-членів АСЕАН, а також виваженій зовнішній політиці, країна домоглась особливої прихильності інвесторів і торговельних партнерів цього інтеграційного угруповання. Приділено значну увагу розвиткові зовнішніх відносин та співробітництва В'єтнаму з такими країнами як Китай, Японія, Індія, Сполучені Штати Америки, країни Європейського Союзу та Російська Федерація. Окремо досліджено історію розвитку політичних відносин В'єтнаму та України, проаналізовано передумови успішної реалізації національних економічних інтересів України у відносинах з В'єтнамом та вихід на перспективні торговельно-економічні та інвестиційні ринки не тільки цієї країни, але й країн-членів АСЕАН.

Ключові слова: модернізація; оновлення; рух неприєднання; АСЕАН; АTEC; COT; ЮНІДО; спільна міжурядова комісія.

( Andriy Kudryachenko, Yevhen Prypik

Надійшла до редакції: 30.03.2020

Прийнята до друку: 13.04.2020 